\title{
Evaluation of Different Virginia-Type Groundnut Varieties Suitable Under Central Dry Zone of Karnataka, India
}

\author{
A.H. Kumar Naik ${ }^{1 *}$, N. Pallavi ${ }^{1}$ and H.G. Sannathimmappa ${ }^{2}$ \\ ${ }^{1}$ All India Coordinated Research Project on Groundnut, Zonal Agricultural and Horticultural \\ Research Station, Babbur Farm, Hiriyur, Karnataka-577 598, India \\ ${ }^{2}$ Departmnet of agronomy, Agricultural and Horticultural Research Station, Kathalagere, \\ Davanagere, Karnataka, India \\ *Corresponding author
}

\section{Keywords}

Groundnut, Oilseed, Genotype, Yield

Article Info

Accepted:

26 December 2017

Available Online:

10 January 2018

\section{A B S T R A C T}

The groundnut, an important protein crops in India grown under rain-fed conditions. It is one of the world's principal oilseed crops, widely grown in areas ranging from latitude $40^{\circ} \mathrm{N}$ to $40^{\circ} \mathrm{S}$. Nuts are eaten in a variety of forms, or crushed to provide vegetable oil for human consumption and protein rich meal for livestock's. However, there has been a consistent fluctuation in the area and production over years and across the states. The main focus of the groundnut improvement program was to see the performance of different Virginia-type groundnut varieties suitable under Central Dry zone of Karnataka. In this regard, Experiment was conducted during Kharif 2015-16 at Zonal Agricultural and Horticultural Research station, Hiriyur, Chitradurga District. The present investigation consists of 11 entries sponsored by Directorate of Groundnut Research, Junagadh, Gujarat to see the performance of different Virginia-type groundnut varieties with an objective of exploiting suitable groundnut varieties under Central Dry zone of Karnataka. This investigation revealed that traits like 100 seed weight and haulm yield/ha recorded significant difference among different entries, further the entry NRCG CS 414 recorded the higher pod yields of $2891 \mathrm{~kg} / \mathrm{ha}$.

\section{Introduction}

In India the groundnut, which was introduced around 250 years ago, is the most important oilseed crop of the country. Now it is grown on an area of about $8 \mathrm{~m}$ ha, in 260 districts, mostly as rain fed crop on well drained sandy soils in $500-2000 \mathrm{~mm}$ annual rainfall areas producing about 8 million tones. Up to 1960 s the groundnut, in India was grown only in rainy season (Kharif), but from 1971-72 its cultivation started in winter (Rabi) and summer also where it showed higher yield potential than Kharif. Presently, India has the largest groundnut area (32\% of the world) and also till 1992 was the chief - producer of groundnut in the world. But, from 1993 onwards, China, due to its higher productivity than India, became the highest producer of groundnut and India stands second. In present scenario of increasing population as well as malnutrition problem, the production of 
groundnut has to be increased to meet the demand both as oilseeds as well as food crop. As groundnut is an energy rich crop requiring more energy for oil and protein synthesis, comparative to other crops, its productivity cannot be increased after certain limit and its area in the traditional groundnut - growing belt is decreasing, the expansion of groundnut cultivation in central dry zone of Karnataka is areas of the alternative with suitable cultivar (Singh et al., 2006).

Thus efforts were made during the last one decade, to popularize groundnut suitable groundnut varieties in these areas where there is tremendous scope to increase the production and productivity through introduction of new crop varieties. Hence, AICRP on Groundnut an attempt has been made to study the different entries suitable to Central Dry Zone of Karnataka.

\section{Materials and Methods}

The proposed study was conducted at the Zonal Agricultural and Horticultural Research Station, Hiriyur $\left(13^{0} 57^{\prime} 32^{\prime}\right.$ N, $70^{0} 37^{\prime} 38^{\prime}$ E, 606 MSL), University of Agricultural and Horticultural Sciences, Shivamogga, India. The soil of the experimental sites belonged to medium black soil having $\mathrm{pH}$ of 7.7 , low available nitrogen $\left(162 \mathrm{~kg} \mathrm{ha}{ }^{-1}\right)$ and phosphorus (16.2 $\left.\mathrm{kg} \mathrm{ha}^{-1}\right)$, medium available potassium $\left(270 \mathrm{~kg} \mathrm{ha}^{-1}\right)$.

The material for the present study comprised of 11 different entries, sponsored by Directorate of Groundnut Research, Junagadh, Gujarat. Experiment was conducted during Kharif 2015-16 at Zonal Agricultural and Horticultural Research Station, Hiriyur, Chitradurga district on performance of different Virginia-type groundnut varieties with an objective of exploiting suitable groundnut varieties under Central Dry zone of Karnataka. The experiment was laid out in a
Randomized Complete Block Design (RCBD), at four replications with recommended dose of fertilizers with plot size of $5.0 \times 2.25 \mathrm{~m}$ with inter and intra row spacing of $45 \mathrm{~cm}$ and $15 \mathrm{~cm}$ respectively. To avoid border effect, one border row plants in all 4 sides of the plot were excluded from the plot yield. Required agronomic and plant protection practices were followed during crop growth period to raise a good crop.

During harvest time, five representative plants were collected in net plot randomly from each plot. Data were recorded on plant stand at time of harvesting, $50 \%$ flowering, plant height (cm), Shoot Length $(\mathrm{cm}), 100$ seed weight $(\mathrm{g})$, shelling percentage $(\%)$, pod yield $(\mathrm{Kg} / \mathrm{ha})$, Kernel yield ( $\mathrm{Kg} / \mathrm{ha})$, Haulm yield/ ha. All the data on growth, yield and other yield attributes were analyzed statistically.

\section{Results and Discussion}

The study revealed that traits like 100 seed weight and haulm yield/ha showed significant difference among entries, further there was a non-significant difference observed for pod yield and kernel yield among the entries. However the entry NRCG CS 414 recorded the higher pod yields of $2891 \mathrm{~kg} / \mathrm{ha}$. The present results were in agreement with the findings of earlier study of Madhusudhana, (2013).

Further, as observed in the present study, Awal and Ikeda, (2003) as also reported the generative growth constitutes the development and growth of reproductive parts. From yield point of view, this phase assumes significance as the sink lies in the reproductive parts. Hence, the detailed observations were made on various aspects of generative growth at the stage of maturity. The number of flowers, pegs, and pods are the most important yield components that affect the yield potential of groundnut (Table 1). 
Table.1 Analysis of variance for yield and yield attributing characters in different groundnut varieties

\begin{tabular}{|l|c|c|c|c|c|c|c|c|c|}
\hline \multicolumn{1}{|c|}{ Treatments } & $\begin{array}{c}\text { Final } \\
\text { plant } \\
\text { count }\end{array}$ & $\begin{array}{c}\text { Days to } \\
\mathbf{5 0} \% \\
\text { flowering }\end{array}$ & $\begin{array}{c}\text { Plant } \\
\text { height } \\
(\mathbf{c m})\end{array}$ & $\begin{array}{c}\text { Shoot } \\
\text { length } \\
(\mathbf{c m})\end{array}$ & $\begin{array}{c}\mathbf{1 0 0} \text { seed } \\
\text { weight } \\
(\mathbf{g})\end{array}$ & $\begin{array}{c}\text { Shelling } \\
\%\end{array}$ & $\begin{array}{c}\text { Kernel } \\
\text { yield/ ha }\end{array}$ & $\begin{array}{c}\text { Pod yield } \\
\text { (kg/ ha) }\end{array}$ & $\begin{array}{c}\text { Haulm } \\
\text { yield/ ha }\end{array}$ \\
\hline PBS 22080 & 131 & 34 & 42 & 31 & 54.9 & 74 & 1866 & 2496 & 3972 \\
\hline JSP 61 & 147 & 34 & 54 & 43 & 54.0 & 69 & 1973 & 2797 & 6563 \\
\hline PBS 25033 & 152 & 34 & 47 & 35 & 42.8 & 65 & 1711 & 2393 & 3477 \\
\hline RG 595 & 145 & 33 & 54 & 43 & 65.0 & 68 & 1880 & 2780 & 5705 \\
\hline JSP 60 & 150 & 33 & 54 & 44 & 51.9 & 70 & 2036 & 2790 & 5351 \\
\hline RG 532 & 143 & 34 & 53 & 42 & 53.9 & 73 & 1690 & 2292 & 6438 \\
\hline NRCG CS 414 & 146 & 34 & 56 & 42 & 70.5 & 69 & 1804 & $\mathbf{2 8 9 1}$ & 5403 \\
\hline CSMG-2010-11 & 150 & 34 & 49 & 38 & 68.6 & 72 & 1673 & 2522 & 4229 \\
\hline KDG 128 (ZC) & 150 & 33 & 50 & 39 & 51.4 & 74 & 2290 & 2934 & 5014 \\
\hline CG 18 (ZC) & 153 & 34 & 59 & 46 & 60.7 & 74 & 2088 & 2844 & 5398 \\
\hline ICGV 00348 & 140 & 34 & 47 & 35 & 46.7 & 70 & 1942 & 2678 & 4742 \\
\hline (ZC) & & & & & & & & \\
\hline
\end{tabular}

The present study confirms that groundnuts are a valuable source of protein, fat, energy, and minerals and generate cash income to many poor farmers in the developing world. Suitable variety and plant density in a given area greatly determines growth and development of crops particularly the yield components and yield.

\section{Acknowledgement}

The authors would like to thank the Directorate of Groundnut Research, Indian council of agricultural research station, Junagadh, Gujarat, India and also Zonal Agricultural and Horticultural research station, for providing the necessary facilities required conducting this trial.

\section{References}

Awal, M.A. and Ikeda, T. 2003. Controlling canopy formation, flowering, and yield in field-grown stands of peanut (Arachis hypogaea L.) with ambient and regulated soil temperature. Field Crops Res. 81: 121-132.

Madhusudhana, B. 2013. "A Survey on Area, Production and Productivity of Groundnut Crop in India”, IOSR, Volume 1, Issue 3 (Sep. - Oct. 2013), 01-07.

Singh, A.L., Basu, M.S., Mundra, G. C., Patel, D. P. and Mausumi Raychaudhuri, 2006. Groundnut cultivation technologies for North Eastern Hills of India. NRCG, 1-3.

\section{How to cite this article:}

Kumar Naik, A.H., N. Pallavi and Sannathimmappa, H.G. 2018. Evaluation of Different Virginia-Type Groundnut Varieties Suitable Under Central Dry Zone of Karnataka, India. Int.J.Curr.Microbiol.App.Sci. 7(01): 2933-2935. doi: https://doi.org/10.20546/ijcmas.2018.701.351 